\title{
Wpływ smogu na projektowanie obiektów sportowych $^{1}$
}

\section{Wojciech Zabłocki}

\begin{abstract}
Zjawisko smogu i związane z nim konsekwencje zdrowotne znalazły się obecnie $\mathrm{w}$ centrum uwagi wielu społeczeństw, także w Polsce. Oprócz przeciwdziałania powstawaniu smogu powstaje pytanie, jaki wpływ może on mieć na planowanie urbanistyczne i projektowanie architektoniczne. W artykule tym próbuję odpowiedzieć na pytanie, jaka może być relacja miedzy faktem powstawania smogu, szczególnie $\mathrm{w}$ miastach, a planowaniem i projektowaniem obiektów sportowych.
\end{abstract}

Opinia lekarzy jest jednoznaczna: w zasadzie sa tylko trzy skuteczne metody ochrony człowieka przed szkodliwym pyłem, zawieszonym w powietrzu. Są to:

niewychodzenie $\mathrm{z}$ domu w czasie wysokiego poziomu smogu, unikanie wysiłku fizycznego, szczególnie na zewnątrz, stosowanie masek przeciwpyłowych. Jednak stosowanie masek w czasie wysiłku nie jest zdrowe, bowiem ogranicza wentylację organizmu (ryc. 1).

Przeciętne stężenie smogu jest różne w rozmaitych lokalizacjach i może być monitorowane za pomoca sieci sensorów. Wyniki te, moga w przyszłości być uwzględniane przy wydawaniu lokalizacji i stanowić jeden z elementów planów.

\footnotetext{
${ }^{1}$ Z wielka przyjemnością, a zarazem z wielkim smutkiem prezentujemy Państwu krótki artykuł autorstwa Profesora Wojciecha Zabłockiego. Z przyjemnościa, ponieważ tekst dotyczy bardzo ważnego, aktualnego i globalnego problemu, pokazuje, że nawet w ostatnich latach życia Profesor koncentrował się na istotnych sprawach życia codziennego, potrafił powiązać je ze swoim ukochanym sportem, prezentował naukowy model widzenia i objaśniania otaczającej nas rzeczywistości.

Ze smutkiem, ponieważ jest to ostatni tekst Profesora, który wpłynął do naszej redakcji, symboliczna "kropka nad i" sportowego, zawodowego, naukowego i artystycznego dorobku.
}

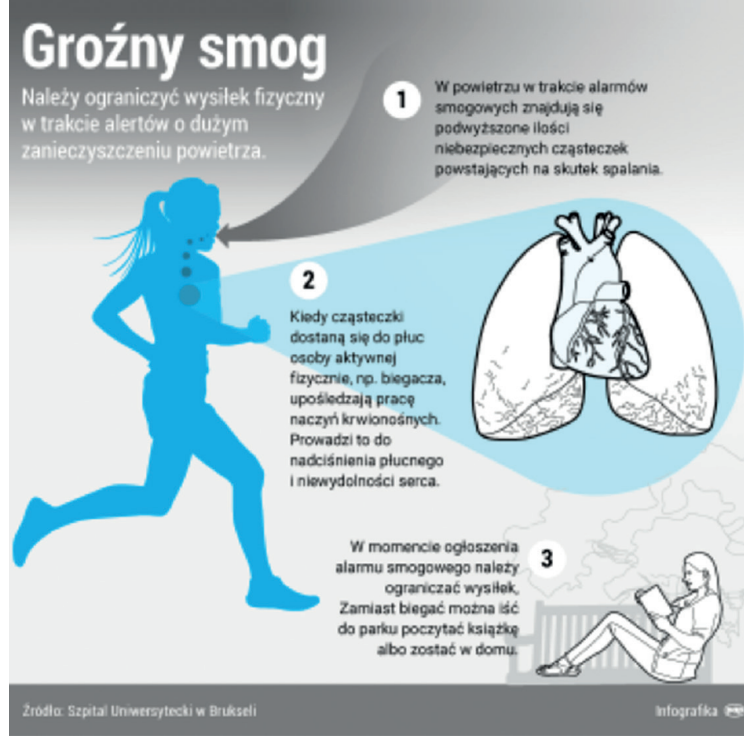

Ryc. 1. Wysiłek fizyczny na powietrzu w czasie alertów smogowych jest niekorzystny dla organizmu

Źródło: http://zdrowie.pap.pl 
Smog generowany jest $\mathrm{w}$ dużej mierze przez transport kołowy, dlatego sytuowanie obiektów sportowych, szczególnie obiektów otwartych, blisko ruchliwych ulic i skrzyżowań, stwarza ryzyko dla użytkowników. Pomysły sytuowania obiektów rekreacyjnych, jak korty tenisowe lub baseny na dachach obiektów komercyjnych lub hotelowych w intensywnej miejskiej zabudowie uważam za chybione (ryc. 2).

Należy sobie zdawać sprawę, że większość otwartych stadionów, także w Warszawie, znajduje się

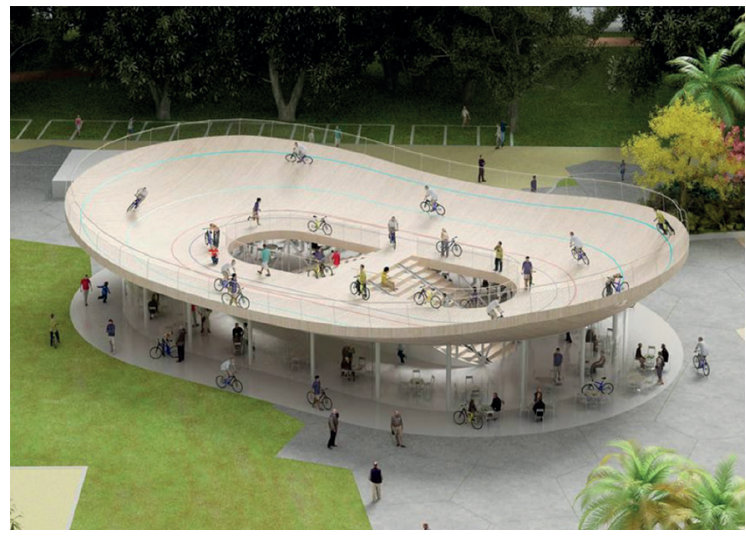

Ryc. 2. Welodrom na dachu kawiarni w Chińskiej prowincji Hainan

Projektowali NL architekci z Amsterdamu

Źródło: informacje prasowe TVN24.pl $\mathrm{w}$ centrum miasta i otoczone jest ruchliwymi arteriami komunikacyjnymi i parkingami. Terminy rozgrywek na stadionach nie mogą być zależne od komunikatów smogowych. Zarówno zawodnicy, jak i widzowie mogą być narażeni na szkodliwe działanie pyłów zawieszonych podczas trwania meczu. Widzowie mogą nosić maski, a zawodnicy powinni być poddawani po wysiłku odpowiedniej terapii, niwelującej szkodliwe działanie smogu. Lokalizowanie nowych stadionów powinno wynikać ze wskazówek monitoringu antysmogowego. Dodatkowym czynnikiem projektowania będzie naturalna wentylacja areny stadionu i trybun.

Specjalną uwagę należy zwrócić na lokalizację otwartych stadionów treningowych dla młodzieży, która jest bardziej wrażliwa na działanie smogu, niż wytrenowani zawodnicy. Młodzieżowe obiekty terenowe powinny znajdować się na terenach otwartych, zazielenionych, dobrze przewietrzanych. Ujemnym przykładem jest np. lokalizowanie boisk dla treningu młodzieży przy stadionie Legii w Warszawie, u zbiegu ruchliwych arterii.

Pewien problem stanowią boiska szkolne, ponieważ szkoły lokalizowane są także na terenach, nawiedzanych często przez smog. W czasie alertów uczniowie moga ćwiczyć w szkolnych salach sportowych. Boiska typu Orliki powinny mieć także do dyspozycji sale sportowe. Najlepszym rozwiązaniem do zapewnienia uprawiania sportu i rekreacji w każdych warunkach są oczywiście obiekty zamknięte, w miarę możliwości klimatyzowane. Liczba ich jest ograniczona ze względu na wysokie koszty budowy i eksploatacji.

W czasie, gdy nie występują alerty smogowe, nic nie stoi na przeszkodzie w uprawianiu sportu i rekreacji na świeżym powietrzu. Przykładem moga być zawody rowerowe i biegi uliczne. 


\section{The impact of smog on the design of sports facilities}

\section{ABSTRACT}

The smog phenomenon and its health consequences seem to be nowadays a real problem for many societies, including Poland. In addition, the question arises as to what impact it may have on urban planning and architectural design. Scientists believe that there are only three methods to avoid the dangerous smog pollution: trying to stay indoors during smog alerts, avoiding outdoor exercise and using special masks. However, using masks during exercising is unhealthy due to the reduction of the body's oxygenation. Special attention should be paid to the location of open sports areas for young citizens. Air-conditioned sports halls would be the best option for those who want to be physically active during smog alerts.

Słowa kluczowe: smog, stadiony i boiska, sale sportowe

Key words: smog, stadiums and playing fields, sports halls 